\title{
The Law of Transboundary Aquifers: Many Ways of Going Forward, but Only One Way of Standing Still
}

\author{
Gabriel Eckstein and Francesco Sindico
}

The international community has been considering international legal norms and policies for the management of transboundary aquifers for more than ten years. In 2008, the International Law Commission provided a framework with the adoption of the Draft Articles on the Law of Transboundary Aquifers, which are now formally annexed to a United Nations General Assembly (UNGA) Resolution. Since 2008, the topic of the law of transboundary aquifers has thrice been placed on the agenda of the UNGA Sixth Committee with a specific mandate to discuss the future form of the Draft Articles. This article explores the options before the international community regarding the future form of the Draft Articles and considers the possible advantages and disadvantages of each option. The article also discusses the extent to which the actual form of the Draft Articles matters in itself, or whether the impact of the Draft Articles ultimately will depend on other factors.

\section{INTRODUCTION}

Groundwater resources play a critical role in providing fresh water for people, industries, nations and the environment worldwide. Globally, groundwater provides approximately $45 \%$ of humanity's freshwater needs for everyday domestic uses, such as drinking, cooking and hygiene, as well as $24 \%$ of water used in irrigated agriculture. ${ }^{1}$ In many cases, groundwater is found in aquifers that are transboundary. ${ }^{2}$ While 276 international watercourses traverse the world's land areas, ${ }^{3}$ an ongoing study has identified, to date, 448 aquifers and aquifer bodies traversing international political boundaries. ${ }^{4}$ In places like the Middle East, North Africa, and the Mexico-United States (US) border, transboundary aquifers serve as the primary or sole source of available freshwater for human and environmental sustenance.

Recognizing the particular importance of transboundary aquifers, nations and international agencies around the world have begun exploring mechanisms for governing these hidden resources. This includes formal efforts to manage and regulate transboundary aquifers, such as the rigorous scheme implemented on the Genevese Aquifer along the French-Swiss border, ${ }^{5}$ to more general cooperative regimes, such as the Guarani Aquifer Agreement in South America, ${ }^{6}$ to instruments aimed mainly at an initial exchange of scientific data, as

\footnotetext{
${ }^{1}$ J. Margat and J. van der Gun, Groundwater Around the World: A Geographic Synopsis (CRC Press 2013), at 149.

${ }^{2}$ It is important to highlight that groundwater is just one component of an aquifer; an aquifer is the geological formation that contains the groundwater. According to the International Law Commission Draft Articles on the Law of Transboundary Aquifers, an aquifer is 'a permeable water bearing geological formation underlain by a less permeable layer and the water contained in the saturated zone of the formation'. The Law of Transboundary Aquifers (UNGA Resolution A/RES/63/124, 11 December 2008), Article 2a.

${ }^{3}$ P. Wouters and R. Moynihan, 'Benefit Sharing in the UN Watercourses Convention and under International water law', in: F. Rocha Loures and A. Rieu-Clarke (eds.), The UN Watercourses Convention in Force: Strengthening International Law for Transboundary Water Management (Routledge, 2013), 336.

${ }^{4}$ See IGRAC, 'Transboundary Aquifers of the World - Update 2012, Special Edition for the 6th World Water Forum, Marseille', found at: <http://www.un-igrac.org/dynamics/modules/SFIL0100/view.php?fil Id=213>.

${ }^{5}$ Convention Relative a la Protection, a l'Utilisation, a la Realimentation et au Suivi de la Nappe Souterraine Franco-Suisse du Genevois (18 December 2007; in force 1 January 2008).

${ }^{6}$ Acuerdo Sobre el Acuífero Guarani (San Juan, Argentina, 2 August 2010; not yet in force), ('Guarani Aquifer Agreement'). An English version of the Agreement can be found at: $<$ http://www.internationalwaterlaw.org/documents/regionaldocs/Guarani_Aquifer_Agreement-English.pdf $>$.
} 
developed for the Nubian Sandstone and North Western Sahara aquifer systems in Northern Africa. ${ }^{7}$ It also includes informal efforts forged by subnational political entities, like the unofficial arrangements crafted for the Hueco Bolson aquifer underlying the cities of Juárez and El Paso on the Mexico-US border, ${ }^{8}$ and for the Abbotsford-Sumas Aquifer between the US state of Washington and the Canadian province of British Columbia. ${ }^{9}$

Possibly the most significant global effort to address the governance of transboundary aquifers is that undertaken by the United Nations (UN) International Law Commission (ILC). In December 2008, following six years of intense research and debate, the UN General Assembly (UNGA) adopted Resolution 63/124, which contains nineteen Draft Articles on the Law of Transboundary Aquifers. ${ }^{10}$ Prepared by the ILC, the Draft Articles were modelled, largely, on the 1997 UN Watercourses Convention (UNWC). ${ }^{11}$ Since 2008, the Draft Articles have thrice been on the agenda of the UN General Assembly for the purpose of discussing the future form of the principles and norms articulated in the ILC's work product. In 2008 and 2011, the topic was tabled for consideration at subsequent meetings. In October and November 2013, the Draft Articles were again raised at the UNGA and their status and final form considered. While the member States gave the topic considerable attention, they again failed to form a consensus on whether and how to move the topic forward.

This article explores the options available for the future form of the Draft Articles and considers the advantages and disadvantages of each possibility. It also considers the extent to which that final form may matter for the development or codification of international law, and whether the impact of the Draft Articles could depend on other factors. The article begins by reviewing the work of the ILC in developing the Draft Articles. It then analyses the various options for their future form that have been proffered by various governments, scholars, and international organizations, including as an independent treaty, a protocol to the UNWC, and a statement of guidelines. In this context, it also considers the impact of maintaining the status quo, meaning no action by the UN General Assembly. Finally, the article assesses the relationship between the future form of the Draft Articles and their relevance to the future development and codification of international law for transboundary aquifers.

\footnotetext{
7 The Nubian Sandstone Aquifer System underlies the territories of Chad, Egypt, Libya and Sudan. See Programme for the Development of a Regional Strategy for the Utilisation of the Nubian Sandstone Aquifer System (NSAS) - Terms of Reference for the Monitoring and Exchange of Groundwater Information of the Nubian Sandstone Aquifer System (Tripoli, 5 October 2000), found at: $<$ http://www.fao.org/docrep/008/y5739e/y5739e05.htm>. The North Western Sahara Aquifer System underlies Algeria, Libya and Tunisia. See Establishment of a Consultation Mechanism for the Northwestern Sahara Aquifer System (SASS) (Rome, 19-20 December; endorsed 6 January 2003 (Algeria), 15 February 2003 (Tunisia), 23 February 2003 (Libya)), found $<$ http://www.fao.org/docrep/008/y5739e/y5739e05.htm\#bm05.2.1>.

${ }^{8}$ Memorandum of Understanding between City of Juárez, Mexico Utilities and the El Paso Water Utilities Public Services Board of the City of El Paso, Texas (6 December 1999), found at: $<$ http://internationalwaterlaw.org/documents/regionaldocs/Local-GW-Agreements/El_Paso-Juarez_MoU.pdf>.

${ }^{9}$ Memorandum of Agreement Related to Referral of Water Right Applications Related to the Transboundary Abbotsford-Sumas Aquifer between the State of Washington as Represented by the Department of Ecology and the Province of British Columbia as Represented by the Minister of Environment, Lands and Parks (10 October 1996), found at: <http://internationalwaterlaw.org/documents/regionaldocs/Local-GW-Agreements/1996-BCWA-Water-Right-Referral-Agreement.pdf>.

${ }^{10}$ UNGA Resolution A/RES/63/124, n. 2 above.

11 Convention on the Law of the Non-navigational Uses of International Watercourses (New York, 21 May 1997; not yet in force) ('UNWC').
} 


\section{THE LAW OF TRANSBOUNDARY AQUIFERS}

Historically, groundwater resources were treated by nations, water law scholars, and practitioners akin to an unwanted stepchild. They were either ignored, cursorily misunderstood, or intentionally disregarded, resulting in their omission from public and political discourse and consideration. This was especially true in the international transboundary context, where the number of international agreements for transboundary rivers and lakes continues to vastly outnumber those applicable to transboundary aquifers. ${ }^{12}$

The earliest articulation of an international legal regime specifically applicable to these transboundary ground water resources is found in the work of the International Law Association in its so-called Helsinki Rules of 1966 and Seoul Rules of $1986 .{ }^{13}$ While the product of an unofficial, non-governmental organization, the norms articulated in its instruments have been recognized as foundational for subsequent efforts. More recently, the UNWC indirectly adopted some of the notions put forward by the International Law Association, when it applied its proposed regime to transboundary aquifers that were hydraulically connected to transboundary rivers or lakes. ${ }^{14}$ That latter effort, though, was not comprehensive and left numerous gaps in the management and regulatory regime applicable to transboundary aquifers. ${ }^{15}$

In 2002, at the request of the UNGA, the ILC began working on the topic of 'shared natural resources'. While the effort was conceptualized to encompass water, oil, gas and other natural resources that traversed international political boundaries, in 2003 the ILC decided to confine its initial work to the subject of transboundary ground water resources. Its objective was to build on its prior work on transboundary watercourses (which resulted in the UNWC), and to address those transboundary aquifers that were excluded under the UNWC. Under this mandate, the ILC elected Ambassador Chusei Yamada of Japan as its Special Rapporteur for the topic and embarked on a rigorous study of the law, science and policy of transboundary aquifers globally. ${ }^{16}$

\footnotetext{
${ }^{12}$ G. Eckstein and Y. Eckstein, 'A Hydrogeological Approach to Transboundary Ground Water Resources and International Law', 19:2 American University International Law Review (2003), 222. In contrast to the handful of transboundary aquifer agreements currently in force (all of which were forged in the past 35 years), more than 3,600 treaties governing transboundary rivers and lakes have been implemented over the past 1,200 years. United Nations Environment Programme (UNEP), Atlas of International Freshwater Agreements, United Nations Environment Programme (UNEP, 2002), at 6.

${ }^{13}$ International Law Association, The Helsinki Rules on the Uses of the Waters of International Rivers, in: Report of the Fifty-Second Conference (August 1966), 484, Article II; and International Law Association, The Seoul Rules on International Groundwaters, in: Report of the Sixty-Second Conference (August 1986).

${ }^{14}$ UNWC, n. 11 above, Article 2(a).

${ }^{15}$ Gaps in the UNWC, as it applies to ground water resources, include the Convention's non-applicability to transboundary fossil aquifers and, more generally, to transboundary aquifers without a hydraulic link to a transboundary surface water body. See G. Eckstein, 'A Hydrogeological Perspective of the Status of Ground Water Resources Under the UN Watercourse Convention', 30:3 Columbia Journal of Environmental Law (2005), 529. The ILC sought, at least, to partly bridge this gap through the adoption of the 1994 ILC Resolution on Confined Transboundary Groundwater, which can be found in: Yearbook of the International Law Commission 1994, Volume II, Part 2 (UN Doc. A/CN.4/SER.A/1994/Add.1, 1994), 135. This effort, though, has been criticized as both inadequate and technically imprecise. See C. Yamada, Shared Natural Resources: Addendum to the First Report on Outlines (UN Doc. A/CN.4/533/Add.1, 30 June 2003), at paragraph 5; and G. Eckstein and Y. Eckstein, n. 12 above, 251.

${ }^{16}$ On the process at the ILC and its work on the law of transboundary aquifers see R.M. Stephan, 'The Draft Articles on the Law of Transboundary Aquifers: The Process at the UN ILC', 13:3 International Community Law Review (2011), 223.
} 
In late 2008, following six years of intense research and debate, and five reports and supplements prepared by Ambassador Yamada, the UN General Assembly adopted a resolution containing nineteen Draft Articles on Transboundary Aquifers. ${ }^{17}$ The resolution recognized the work of the ILC, and commended the Draft Articles 'to the attention of Governments without prejudice to the question of their future adoption or other appropriate action'. ${ }^{18}$ It also expressed its appreciation to the UNESCO International Hydrological Programme (UNESCO-IHP), which had been instrumental in providing scientific and technical assistance to the ILC and the Special Rapporteur. ${ }^{19}$ In addition, it encouraged 'the States concerned to make appropriate bilateral or regional arrangements for the proper management of their transboundary aquifers, taking into account the provisions of these draft articles' ${ }^{20}$ Finally, it placed the topic of the law of transboundary aquifers on its provisional meeting agenda three years hence. ${ }^{21}$

Since that initial consideration, the law of transboundary aquifers has been discussed by the UNGA's Sixth Committee on two occasions, in 2011 and 2013. In both sessions, while some delegates offered substantive comments on the Draft Articles, the primary focus was on their final form. Some delegates favoured commencing deliberation on a binding treaty, either immediately or in a stepped fashion. Other argued that codification was premature because of a lack of State practice evidencing the status of the international law of transboundary aquifers. Still others, while sceptical of the state of international law on the subject, suggested adopting the Draft Articles in the form of a resolution or declaration of principles that could serve as guidelines as States explore their applicability in bilateral or regional agreements. ${ }^{22}$

In 2011, the UNGA took note of the importance of 'the need for reasonable and proper management of transboundary aquifers', further encouraged the member States 'to make appropriate bilateral or regional arrangements for the proper management of their transboundary aquifers, taking into account the provisions of the draft articles', ${ }^{23}$ and tabled consideration of the final form of the Draft Articles to its meeting in $2013 .{ }^{24}$ UNESCO-IHP was referred to specifically and encouraged 'to offer further scientific and technical assistance to the States concerned'.25

The discussions before the UNGA in late 2013 did not differ significantly from those of prior deliberations. Countries continued to disagree over the status to be given to the Draft Articles and over their future form. Despite the discord, the UNGA agreed, once more, to postpone

17 On the Draft Articles, see K. Mechlem, 'Moving Ahead in Protecting Freshwater Resources: The International Law Commission's Draft Articles on Transboundary Aquifers', 22:4 Leiden Journal of International Law (2009), 801; S. McCaffrey, 'The International Law Commission Adopts Draft Articles on Transboundary Aquifers', 103:2 American Journal of International Law (2009), 72; and G. Eckstein, 'Commentary on the U.N. International Law Commission's Draft Articles on the Law of Transboundary Aquifers', 18:3 Colorado Journal of International Environmental Law and Policy (2007), 537.

${ }^{18}$ UNGA Resolution A/RES/63/124, n. 2 above.paragraph 4.

${ }^{19}$ Ibid., at paragraph 3.

${ }^{20}$ Ibid., at paragraph 5 (emphasis added).

${ }^{21}$ Ibid., at paragraph 6.

${ }^{22}$ For a review of the 2013 session, see below. See also UNGA Sixth Committee: Summary Record of the 16th meeting (UN Doc. A/C.6/66/SR.16, 14 February 2012); UNGA Department of Public Information, News and Media Division, Sixth Committee, 16th Meeting: Praising Draft Texts on Transboundary Harm, Aquifers, Allocation of Loss, Delegates Disagree Over Final Forms, Seek Further Examination (UN Doc. GA/L/3464, 22 October 2013).

${ }^{23}$ The Law of Transboundary Aquifers (UNGA Resolution A/RES/66/104, 13 January 2012), at paragraph 1.

${ }^{24}$ Ibid., at paragraph 3.

${ }^{25}$ Ibid., at paragraph 2 . 
further consideration of the law of transboundary aquifers until $2016 .{ }^{26}$ It also encouraged UNESCO-IHP to continue its valuable work. ${ }^{27}$ Where the outcome did change is in the relationship put forward between States interested in taking forward more cooperative approaches in the management of transboundary aquifers and the Draft Articles. Significantly, the latest resolution makes no reference to the final form of the Draft Articles. The resolution, however, commends: 'to the attention of Governments the draft articles on the law of transboundary aquifers annexed to the present resolution as guidance for bilateral or regional agreements and arrangements for the proper management of transboundary aquifers.... 28

Until this resolution, countries were only commended to 'take into account' the Draft Articles when discussing bilateral or regional agreements. This latest resolution, however, appears to elevate the Draft Articles to the status of 'guidance' in the negotiation of future bilateral and regional transboundary aquifer agreements. This is not simply a change in language or use of synonymous wording. Rather, use of the term 'guidance' suggests both a stronger recognition of the Draft Articles by the international community and a more assertive admonition to States to abide by the norms contained therein.

Notwithstanding the 'guidance' language, what started out as a relatively quick process in terms of the development of international law, has now slowed down to a crawl. While the Draft Articles were drafted in only six years, since 2009 there have been no amendments to the proposed norms and there has been little progress toward a consensus on next steps. This is particularly evident with respect to the legal form that the Draft Articles should take. The international community in 2014 has before it exactly what it had at the beginning of 2009: a set of ILC Draft Articles annexed to an UNGA resolution, all of which remain in limbo.

Does this lack of progress on the final form of the Draft Articles suggest that their content is premature or ill-conceived? Might it portend the demise of the effort to formulate legal norms for the management of transboundary aquifers? Or, does the continued postponement intimate an alternative route toward international recognition? The next section of this article considers the various options contemplated and deferred by the UNGA in its successive debates as to the possible forms that the Draft Articles might take. It also assesses those options in the context of transboundary aquifer management.

\section{THE FUTURE FORM OF THE LAW OF TRANSBOUNDARY AQUIFERS}

Despite the apparent lack of progress on the Draft Articles, the debate on their future form is far from over and will continue, at least, into the 2016 session of the UNGA Sixth Committee. This is because the form that an international legal instrument may take is not just a theoretical issue where advocates of soft law versus hard law spend time and effort to justify their position. ${ }^{29}$ Rather, the form can have significant practical relevance and often can

\footnotetext{
${ }^{26}$ Report of the Sixth Committee, The Law of Transboundary Aquifers (UN Doc. A/68/470, 19 November 2013), at paragraph 3. The UNGA adopted the Report without a vote. UNGA Department of Public Information, News and Media Division, Sixty-Eighth General Assembly, Plenary, 68 ${ }^{\text {th }}$ Meeting: Adoption 21 Sixth Committee Resolutions, General Assembly Highlights Significant Achievements in Development of International Law (UN Doc. GA/11473, 16 December 2013).

${ }^{27}$ See Report of the Sixth Committee, n. 26 above, at paragraph 2.

${ }^{28}$ Ibid., at paragraph 1 (emphasis added).

${ }^{29}$ On the debate between hard law and soft law see, for instance, S.I. Karlsson-Vinkhuyzen and A. Vihma, 'Comparing the Legitimacy and Effectiveness of Global Hard and Soft Law: An Analytical Framework', 3:4 Regulation \& Governance (2009), 400. Soft law in the context of international environmental law has been
} 
dictate or direct the extent to which the general principles (both substantive and procedural) present therein can be used, applied and even enforced.

Against this background, the debates before the UNGA have generated a panoply of options for the possible future form of the Draft Articles. Some nations have advocated developing the Articles into an independent framework treaty, while others prefer to present the principals in the form of guidelines or non-binding recommendations. ${ }^{30}$ Finally, there are some countries that prefer maintaining the status quo, which is effectively what has happened until now. Each of these options will now be discussed in turn based, in particular, on the most recent discussions that took place before the UN General Assembly Sixth Committee in October and November 2013. ${ }^{31}$

\section{INDEPENDENT INTERNATIONAL TREATY}

The Draft Articles could serve as a basis to negotiate an independent international convention on the topic of the law of transboundary aquifers. Similarly to what happened with the UN Watercourses Convention, an intergovernmental process could be launched where countries would use the text of the Draft Articles as a starting point to negotiate a final agreement. The resulting convention would then be signed at an international conference and enter into force once the relevant number of ratifications is accrued.

While this option enjoyed several followers in the initial debates on the form of the Draft Articles - even during the drafting of the Articles themselves - more and more States appear to have abandoned this position, albeit for different reasons. These reasons can be broadly divided into three categories: legal, political and socio-economic reasons.

\section{Legal Reasons}

Legal reasons not to back the independent convention option include: disagreement over whether the Draft Articles actually reflect current law and practice applicable to transboundary aquifers; disagreement over whether the Draft Articles collide with other applicable international legal instruments; and disagreement over specific provisions of the Draft Articles.

With regard to the Draft Articles and the state of the law and the practice of States, the positions of Portugal and of the US are instructive. While the former argued that 'the Draft Articles are in line with already existing legal regimes governing water and natural resources in general', ${ }^{32}$ the latter considered that 'many aspects of the draft articles clearly go beyond current law and practice'. 33

discussed by F. Sindico, 'Soft Law and the Elusive Quest for Sustainable Global Governance', 19:3 Leiden Journal of International Law (2006), 829; and P.-M. Dupuy, 'Soft Law and the International Law of the Environment', 12:2 Michigan Journal of International Law (1991).

30 See also C. Yamada, Fifth Report on Shared Natural Resources: Transboundary Aquifers (UN Doc. A/CN.4/59121, 21 February 2008), at paragraphs 7-8.

31 Seventeen countries presented written submissions, which can be found at: $<$ https://papersmart.unmeetings.org/ga/sixth/68th-session/statements/?cv=1\&agenda=7581 $>$.

32 Statement by Portugal, $68^{\text {th }}$ Session of the UN General Assembly Sixth Committee - Agenda Item 87: The Law of Transboundary Aquifers (22 October 2013), found at: $<$ https://papersmart.unmeetings.org/media2/703105/portugal-87.pdf $>$, at 3 .

${ }^{33}$ Statement by the United States of America, $68^{\text {th }}$ Session of the UN General Assembly Sixth Committee Agenda Item 87: The Law of Transboundary Aquifers (22 October 2013), found at: $<$ https://papersmart.unmeetings.org/media2/703097/us-87.pdf $>$, at 2 
In its most recent submission, the US also cautioned against moving toward an independent convention because of the possible overlap of authority and proposed norms between the Draft Articles and UNWC. According to the US, some of the provisions of the Draft Articles would be incompatible with those of the UNWC, thereby creating conflicting obligations and fragmenting international water law. ${ }^{34}$

Raising the possibility that discord over the Draft Articles may spread from its final form to its substance, many nations have raised concerns over specific provisions of the Draft Articles, questioning their merits, appropriateness, and interpretation. Palestine, for example, suggested that it would be unwise to push toward an independent convention when the starting point (the Draft Articles) contain a provision on national sovereignty that, in its opinion, would take the international community back more than a hundred years to the Harmon Doctrine approach to transboundary water management. ${ }^{35}$ In a different vein, Ukraine raised serious concerns with the obligation to not cause significant harm. It questioned the interpretation of the descriptor 'significant' and urged further work and clarification before taking any steps toward an independent convention. More specifically, it questioned the absence of a compensation mechanism for financial losses related to aquifer depletion. ${ }^{36}$

The challenges raised over substantive provisions of the Draft Articles raise a further issue that apparently has not been addressed in the discussions before the UN General Assembly and its Sixth Committee. If an intergovernmental process were launched toward an independent convention, it is by no means certain that the current content of the Draft Articles would be retained. On the contrary, considering the questions and concerns presented in the most recent discussions over certain core areas (i.e., national sovereignty and significant harm) an intergovernmental process could open a Pandora's box of substantive dissent that might lead either to a watering down of the existing Draft Articles or an impasse in achieving consensus, rather than enhancing or adding greater precision to the proposed norms.

\section{Political Reasons}

\footnotetext{
${ }^{34}$ Ibid, at 1 . On this point, see also O. McIntyre, 'International Water Resources Law and the International Law Commission Draft Articles on Transboundary Aquifers: A Missed Opportunity for Cross-Fertilisation?', 13:3 International Community Law Review (2011), 237.

${ }^{35}$ Statement by the State of Palestine, $68^{\text {th }}$ Session of the UN General Assembly Sixth Committee - Agenda Item 87: The Law of Transboundary Aquifers (22 October 2013), found at: $<$ https://papersmart.unmeetings.org/media2/703060/palestine-87.pdf $>$, at 1. Interestingly, many countries actually refer to the principle of national sovereignty as one of the cornerstones of the Draft Articles. See, for example, Statement by Uruguay, $68^{\text {th }}$ Session of the UN General Assembly Sixth Committee - Agenda Item 87: The Law of Transboundary Aquifers (22 October 2013), found at: $<$ https://papersmart.unmeetings.org/media2/703071/uruguay-87.pdf $>$, at 3, and Statement by Peru, $68^{\text {th }}$ Session of the UN General Assembly Sixth Committee - Agenda Item 87: The Law of Transboundary Aquifers (22 October 2013), found at: <https://papersmart.unmeetings.org/media2/703110/peru-87.pdf>, at 1 . National sovereignty in the context of the law of transboundary aquifers has led to very different positions, with $\mathrm{S}$. McCaffrey, n. 17 above, making the same point raised by Palestine, and L. Del Castillo Laborde, 'The Law of Transboundary Aquifers and the Berlin Rules on Water Resources (ILA): Interpretive Complementarity' in: UNESCO-IAH-UNEP, Pre-proceedings: ISARM 2010 International Conference Transboundary Aquifers: Challenges and New Directions (2010), taking a position more close to the ones presented by the two abovementioned Latin American countries.

${ }^{36}$ Statement by Ukraine, $68^{\text {th }}$ Session of the UN General Assembly Sixth Committee - Agenda Item 87: The Law of Transboundary Aquifers (22 October 2013), found at: $<$ https://papersmart.unmeetings.org/media2/703119/ukraine-87.pdf $>$.
} 
Two other reasons against moving towards an independent convention can loosely fall under the category of political constraints and can be framed as a question of political support and scale. According to the US delegation, a future convention on the law of transboundary aquifers 'would [not] garner sufficient support'. ${ }^{37}$ The point raised here goes beyond the question of support needed in the negotiation process of a possible convention, and moves toward the necessary number of ratifications for the possible treaty to enter into force. Given that 16 years since its passage by the UNGA, the UNWC is only now barely on the verge of garnering the requisite number of ratifications, ${ }^{38}$ the question of international political support for a convention on transboundary aquifers may be particularly valid. ${ }^{39}$ Certainly, if a country strongly believes in the value of an international legal instrument and in an independent convention as its form, the lack of support should not prevent that country from considering this form altogether. Nevertheless, the lack of support definitely stands out as a political challenge that needs to be carefully considered when deciding what strategies are pursued.

A second political challenge to an independent convention pertains to a question of scale. There is some disagreement as to whether rules on transboundary aquifer management should be developed at the global level, or if they would be more effective if developed at the level of specific aquifers. Israel advocates this position and argues that local context must be taken into account to the greatest extent, with particular regard given to local hydrogeological and political relationships between the countries overlying a transboundary aquifer. ${ }^{40}$ Similarly, Guatemala supports a 'local solutions' approach. ${ }^{41}$

In response to this latter political challenge, the idiom that all politics are local is apropos. Moreover, the fact that the politics and law of transboundary aquifers are very much intertwined can be readily acknowledged. Nevertheless, there is evidence that international legal frameworks can accommodate local decision making and provide for tailored solutions to local problems. Multilateral environmental agreements are often referred to as framework treaties, ${ }^{42}$ precisely because they provide a common platform upon which to build at the binational or regional level. ${ }^{43}$ Portugal acknowledges this option and argues that a future convention should be flexible enough to allow States to establish specific regimes suitable to their contexts. ${ }^{44}$

\section{Socio-Economic Reasons}

\footnotetext{
${ }^{37}$ See Statement by the United States of America, n. $\underline{33} 34$ above, 1.

38 International Water Law Project, 'Status of the Watercourses Convention', found at: $<$ http://internationalwaterlaw.org/documents/intldocs/watercourse_status.html $>$.

${ }^{39}$ On the current international political support for the UNWC, see A. Rieu-Clarke and F. Loures, 'Still Not in Force: Should States Support the 1997 UN Watercourses Convention?', 18:2 Review of European Community and International Environmental Law (2009), 185, at 190-191.

${ }^{40}$ Statement by Israel, $68^{\text {th }}$ Session of the UN General Assembly Sixth Committee - Agenda Item 87: The Law of Transboundary Aquifers (22 October 2013), found at: $<$ https://papersmart.unmeetings.org/media2/703122/israel-87.pdf $>$, at 2.

${ }^{41}$ Statement by Guatemala, $68^{\text {th }}$ Session of the UN General Assembly Sixth Committee - Agenda Item 87: The Law of Transboundary Aquifers (22 October 2013), found at: $<$ https://papersmart.unmeetings.org/media2/703107/guatemala-87.pdf $>$, at 2.

42 Two examples are the United Nations Framework Convention on Climate Change (Rio de Janeiro, 9 May 1992, in force 21 March 1994), and the Convention on Biological Diversity (Rio de Janeiro, 5 June 1992, in force 29 December 1993).

${ }^{43}$ Even within the few specific treaties on transboundary aquifers, an example can be found. Article 13 of the Guarani Aquifer Agreement, n. 6 above, provides clear legal grounds for specific measures to be adopted in case actions need to take place at a local level in the management of the transboundary aquifer.

${ }^{44}$ See Statement by Portugal, n. 3233 above, at 3.
} 
The last type of reasons against moving toward a convention can be categorized as socioeconomic. Japan hints at this when explaining that despite its past approach favouring a Convention, it now sees this option losing momentum due to the 'sensitivity' of certain countries to 'particular issues'. ${ }^{45}$ Guatemala uses clearer language when it asserts that it finds itself against moving toward an independent convention because of the panoply of economic, political and environmental interests related to the management of transboundary aquifers. Fundamentally, Guatemala argues that, because of socio-economic problems related to the use of groundwater resources in a transboundary aquifer context, their management does not warrant a global treaty. ${ }^{46}$

To paraphrase the idiom related to politics, all socio-economic problems also are local problems. But just as in the political context, an international approach does not necessarily negate recognition of unique local challenges and opportunities for local solutions. Nevertheless, these socio-economic concerns further suggest that there is little appetite for the Draft Articles to be translated into a global independent convention. When taken one at a time, there may be ways to discuss and overcome the various legal, political and socioeconomic challenges raised. Taken together, though, these challenges have created a formidable obstacle that is driving countries away from this form. It is therefore necessary and advisable to move on and consider the other available options regarding the future form of the Draft Articles: their adoption as a declaration of principles or retaining them in their current form.

\section{DECLARATION OF PRINCIPLES}

In his final report, Ambassador Yamada noted: 'While the positions of Governments remain divided, the Special Rapporteur has noticed that some Governments have shifted from supporting a legally binding convention to a non-binding document. ${ }^{47}$ A second option regarding the future form of the Draft Articles therefore is for them to be presented as a declaration of principles. The one immediate difference that such a form would have from their adoption as an independent convention would be their legal nature. While a declaration endorsed by a UN General Assembly resolution would not be legally binding on the member States, a convention would be obligatory under international law. In addition, as a declaration of principles, it would be far easier for an instrument to reflect the current content of the Draft Articles. As noted earlier, if countries were to open an intergovernmental process to negotiate an international convention based on the Draft Articles, it is possible that the content of the Draft Article could be watered down. This risk would likely be lessened if a declaration were adopted. To some extent, there is a political reason for this. Many countries who have objected to the Draft Articles becoming an independent convention have done so because they oppose certain provisions becoming hardened or obligatory by being incorporated in a global convention. It may well be that these countries would soften their objections if the final form is aspirational and imposes no direct liability or obligation. Finally, in contrast to those who frame the declaration approach as a defensive strategy intended to prevent the Draft Articles from becoming binding under a global convention, many advocates for a declaration see it as a constructive first step in the process toward a future convention. ${ }^{48}$ This

\footnotetext{
${ }^{45}$ Statement by Japan, $68^{\text {th }}$ Session of the UN General Assembly Sixth Committee - Agenda Item 87: The Law of Transboundary Aquifers (22 October 2013), found at: $<$ https://papersmart.unmeetings.org/media2/1267523/japan.pdf>, at 3.

${ }^{46}$ See Statement by Guatemala, n. 4142 above, at 2.

${ }^{47}$ See C. Yamada, n. 30 above, at paragraph 8.

${ }^{48}$ See, e.g., Statement by Portugal, n. $\underline{32} 33$ above, at 3.
} 
latter group appears to recognize the challenge of achieving consensus while maintaining their objective of an independent, global convention.

Recognizing the need for compromise, Uruguay, on behalf of the Guarani Aquifer Agreement countries, considered a declaration of principles as the best option for the future form of the draft articles. ${ }^{49}$ Similarly recognizing 'that some member states showed unwillingness to negotiate for a future convention based on the text of the draft articles with their own legitimate interests', Japan shares this position. ${ }^{50}$ However, what is not entirely clear is whether using the Draft Articles as principles and guidelines even requires a new declaration. This takes us to the last of the three options regarding the form of the future draft articles: maintaining the status quo.

\section{MAINTAINING THE STATUS QUO}

A status quo approach suggests no action whatsoever. As seen earlier, the language found in the most recent UNGA resolution on the law of transboundary aquifers has experienced a mild but potentially significant change as compared to the two prior resolutions. States are encouraged not merely to take into account the Draft Articles when negotiating a bilateral or regional agreement for the management of a transboundary aquifer. Rather, they are now commended to use them as guidance in their negotiation. Accordingly, it is arguable that the status quo has already changed. Nevertheless, while most of the countries engaged in the recent debates at the UN General Assembly seem favourable to this language modification, ${ }^{51}$ a considerable number of States appeared to oppose any further action, including the adoption of a non-legally binding declaration of principles.

A few of the arguments repeated by some of the countries justifying the status quo include concerns about the 'maturity' of the Draft Articles. Guatemala and Malaysia, for example, both argue that States should be given more time to familiarize themselves with the Draft Articles before having to decide whether the provisions therein are worthy to be taken into account in possible future negotiations. ${ }^{52}$ This argument raises the question of awareness and understanding of the Draft Articles. As important as groundwater governance and transboundary aquifer management may be, it is still a rather complex and often invisible matter for many governments. The two prior UNGA resolutions referenced the capacity building work of UNESCO-IHP in the field of transboundary aquifer management. That effort has not been limited to increasing the scientific knowledge of transboundary aquifers, which is still referred to by some countries as insufficient, ${ }^{53}$ but also has focused on the legal and institutional options available to countries. The role of UNESCO-IHP is, therefore, crucial for the UNGA process, since the organization is called to clarify the Draft Articles

\footnotetext{
${ }^{49}$ See Statement by Uruguay, n. 3536 above, at 5.

${ }^{50}$ See Statement by Japan, n. 4546 above, at 3.

${ }^{51}$ Statement by Malaysia, 68 ${ }^{\text {th }}$ Session of the UN General Assembly Sixth Committee - Agenda Item 87: The Law of Transboundary Aquifers (22 October 2013), found at: $<$ https://papersmart.unmeetings.org/media2/703081/malaysia-87.pdf $>$; Statement from India, $68^{\text {th }}$ Session of the UN General Assembly Sixth Committee - Agenda Item 87: The Law of Transboundary Aquifers (22 October 2013), found at: <https://papersmart.unmeetings.org/media2/703192/india-87.pdf >; Statement by Guatemala, n. $\underline{4142}$ above; Statement by Peru, n. $\underline{35} 36$ above; Statement by Israel, n. 4041 above; Statement by Palestine, $n$. $\underline{35} 36$ above; and Statement from the United States of America, n. 3334 above.

${ }^{52}$ See Statement by Guatemala, n. 4142 above, at 2; Statement by Malaysia, n. 5153 above, at 1.

${ }^{53}$ See, e.g., Statement by the United States of America, n. 3334 above, at 1; Statement by India, n. 5153 above, at 2 .
} 
and make them more visible. Accordingly, a discussion about the relevance of the future form of the Draft Articles is strongly allied with the work of UNESCO-IHP.

A second reason put forward by States to advocate for the status quo is that the current form of the Draft Articles, as annexed to a UN General Assembly Resolution, provides the necessary flexibility for the Draft Articles to accommodate the local needs and characteristics of different transboundary aquifers. ${ }^{54}$ For example, the US argued that locally unique hydrological, climatic, economic, social, cultural and other factors will require a tailored approach to transboundary aquifer management. ${ }^{55}$ Since this argument is akin to the one considered in the political objection context above, it suffices to say that such concerns do not fully rationalize maintaining the status quo.

\section{THE PROTOCOL OPTION}

Before concluding the discussion of options for the final form of the Draft Articles, it is noteworthy to at least mention a fourth possibility that, while promoted by some organizations, never seemed to gain any traction at the UN. In some circles, the final form of the Draft Articles has been proposed as a protocol to the UNWC. ${ }^{56}$ The chief justifications proffered for this option include the need for a holistic approach to the codification and development of international water law, as well as a coordinated effort for the management of interrelated related surface and ground water resources. ${ }^{57}$ It is unclear why this option did not garner much attention at the UN. Nevertheless, given the current antipathy of the UN member State representatives in the UNGA Sixth Committee to a formal treaty, it is unlikely that this approach could garner any support.

\section{SUMMARY OF THE FUTURE FORM}

In the grand scheme of the development of international law, the first three options all can be regarded as reasonable possibilities. They are not, however, equally realistic or likely to result from the UNGA's deliberations. Legal, political, and socio-economic hurdles make the success of the first option highly improbable with most countries favouring either the declaration or the status quo approach. This reality brings into question whether the form that the Draft Articles may finally take could have an impact on their future relevance. This is the focus of the following section.

\section{THE RELATIONSHIP BETWEEN THE FUTURE FORM AND THE FUTURE RELEVANCE OF THE DRAFT ARTICLES}

\section{METHODICAL DEVELOPMENT}

While the UNGA's approach in assessing the Draft Articles on the Law of Transboundary Aquifers may be frustratingly sluggish, it is possible that, to some extent, the pace of development is intentional. Although the Draft Articles were composed with relative speed -

\footnotetext{
${ }^{54}$ See Statement by the United States of America, n. 3334 above, 1.

55 Ibid.

${ }^{56}$ See e.g., Sixth Committee, Summary Record of the 21st Meeting (UN Doc. A/C.6/59/SR.21, 5 Nov. 2004), at 7; World Wildlife Fund, 'Position Paper: The ILC Draft Articles on the Law of Transboundary Aquifers' (October 2011), found at: <http://www.solutionsforwater.org/wp-content/uploads/2012/01/PP-ILC-draftarticles_Oct2011_final.pdf>.

${ }^{57}$ World Wildlife Fund, n. 5658 above, at 4-5.
} 
in contrast to the 25 years it took to craft the draft articles leading to the UNWC, the Draft Articles were prepared in less than six years - they were not achieved without controversy. ${ }^{58}$ Accordingly, in order to prevent the wholesale rejection of the Draft Articles, some, like Ambassador Yamada, counselled that the UNGA should take a slow but methodical approach to the development of global standards and norms for managing transboundary groundwater resources. To generate eventual acceptance and support for the principles incorporated in the Draft Articles, Ambassador Yamada suggested that the Draft Articles be tabled by the UNGA so as to minimize the pressure that binding norms would engender and allow countries to test run the norms proposed in the Draft Articles. It was Ambassador Yamada's hope that the norms articulated in the Draft Articles might eventually rise to the level of custom, regardless of whether they would ever be codified in a binding legal instrument. ${ }^{59}$ This is the tactic that, while not intentionally, has been successfully pursued by proponents of the UN Draft Articles on the Responsibility of States for Internationally Wrongful Acts. ${ }^{60}$ This is also the option that most countries in the recent 2013 debate on the law of transboundary aquifers at the UN Sixth Committee appeared to favour.

Given the dearth of experience with managing transboundary aquifers, such an organic and measured approach may be justified. On the one hand, it would provide nations the opportunity to experiment with the norms and adapt them to locally-specific or unique circumstances. More importantly, as aquifer riparians begin to utilize, abide by, and modify these principles, it would create the space in which their actions could evolve into demonstrable State practice and, thereby, help create customary international legal norms.

While it is still too early to assess the outcome definitively, the Draft Articles have already begun to influence State practice and the development of international law. For example, the Guarani Aquifer Agreement explicitly references Resolution 63/124 in its preamble. ${ }^{61}$ It also adopts a number of the concepts and norms contained in the Draft Articles, including the principles of sovereignty, cooperation, no significant harm, exchange of data and information, and prior notification of planned works with transboundary implications. ${ }^{62}$

Likewise, the 2009 Bamako Declaration for the Iullemeden Aquifer System directly acknowledges Resolution 63/124, ${ }^{63}$ while the related Memorandum of Understanding implementing the Declaration adopts the principles of equitable and reasonable use, exchange of data and information, and prior notification of planned works with transboundary

\footnotetext{
${ }^{58}$ Some of the more contentious issues before the UN Sixth Committee included the scope of the Draft Articles and their applicability to activities unrelated to the exploitation of an aquifer but which can have a direct impact on the aquifer, the question of sovereignty over portions of a transboundary aquifer found within a State's territory, and prioritization of the rules of no significant harm and equitable and reasonable utilization. See generally G. Eckstein, n. 17 above.

${ }_{99}$ See C. Yamada, n. 30 above, at paragraph 9; and G. Eckstein, 'Notes from the Meeting of Ground Water Experts Group with His Excellency Ambassador Chusei Yamada' (28-31 January 2008, Tokyo, Japan), at paragraph 74 (on file with author).

60 J. Crawford, Articles on Responsibility of States for Internationally Wrongful Acts (United Nations Audiovisual Library of International Law 2012), found at: <http://legal.un.org/avl/pdf/ha/rsiwa/rsiwa_e.pdf $>$, at 2.

${ }^{61}$ On the relationship between the Guarani Aquifer Agreement and the Draft Articles, see F. Sindico, 'The Guarani Aquifer System and the Law on Transboundary Aquifers', 13:3 International Community Law Review (2011), 256.

62 Guarani Aquifer Agreement, n. 6 above.

63 Bamako Declaration for the Iullemeden Aquifer System (Bamako, 20 June 2009), found at: $<\mathrm{http} / /$ www.internationalwaterlaw.org/documents/regionaldocs/Iullemeden_Bamako_Declaration-2009.pdf $>$.
} 
implications, as well as other more progressive norms focusing on human welfare and environmental protection. ${ }^{64}$

Possibly the most significant reference to the Draft Articles can be found in the UNECE Model Provisions on Transboundary Groundwaters, which were adopted by the Meeting of the Parties to the 1992 UN Economic Commission for Europe (ECE) Convention on the Protection and Use of Transboundary Watercourses and International Lakes. ${ }^{65}$ In the commentary appended to the Model Provisions, the UNECE states that:

The present exercise [the Model Provisions on Transboundary Groundwaters] builds on that instrument [the Draft Articles] with a view to providing concrete guidance for implementing, with regard to groundwater, the 1992 Convention on the Protection and Use of Transboundary Watercourses and International Lakes ([UNECE] Water Convention) in the light of the lessons learnt and the experience gained from the implementation of the Convention. ${ }^{66}$

It is significant that the Model Provisions constitute an instrument intended to provide guidance on the subject of transboundary aquifers. Hence, the preamble to Decision VI/2, in which the UNECE adopted the Model Provisions, explicitly '[r]ecogniz[es] the need for providing specific non-binding guidance for the implementation of the Convention with regard to groundwater and facilitating the application of the principles of the Convention to transboundary groundwaters' ${ }^{67}$ Moreover, one of the stated goals of the Model Provisions is to assist 'States sharing transboundary groundwaters intersected by State boundaries or sharing transboundary surface waters linked with groundwaters in drawing up specific agreements addressing the sustainable use, management and protection of those groundwaters through cooperation'. ${ }^{6}$

It is interesting to note that the UNECE Water Convention is now open to all UN Member States. ${ }^{69}$ This effectively means that a legal instrument stemming from such a Convention, albeit in the form of a decision of the Meeting of the Parties, could be relevant for a wider group of countries than those that currently enjoy UNECE membership. The close

\footnotetext{
${ }^{64}$ Memorandum of Understanding Relating to the Setting up of a Consultative Mechanism for the Management of the Iullemeden Aquifer System (Bamako, 20 June 2009), found at: $<$ http://www.internationalwaterlaw.org/documents/regionaldocs/Iullemeden_MoU-2009.pdf>.

${ }^{65}$ Convention on the Protection and Use of Transboundary Watercourses and International Lakes (Helsinki, 17 March 1992; in force 6 October 1996) ('UNECE Water Convention'). The Economic Commission for Europe adopted a decision on Model Provisions on Transboundary Groundwaters at the Meeting of the Parties to the Water Convention on 28-30 November 2012. See UNECE, Decision VI/2, Model Provisions on Transboundary Groundwaters, in: Report of the Meeting of the Parties on its Sixth Session - Addendum: Decisions and Vision for the Future of the Convention (UN Doc. ECE/MP.WAT/37/Add.2, 19 September 2013). Decision VI/2 refers to the Draft Articles in the preamble and adopts, in its operating part, 'the Model Provisions on Transboundary Groundwaters and their commentary as contained in document ECE/MP.WAT/2012/L.5'. Ibid., at 11. For the Model Provisions themselves, see: Draft Model Provisions on Transboundary Groundwaters (UN Doc. ECE/MP.WAT/2012/L.5, 14 September 2012).

${ }^{66}$ See Model Provisions on Transboundary Groundwaters, n. 6567 above, at 4.

${ }^{67}$ UNECE Decision VI/2, n. 6567 above, preamble

${ }^{68}$ Ibid., at 6.

69 UNECE Water Convention, n. 6567 above, Article 25.3 enables '[a]ny other State, not referred to in paragraph 2, that is a Member of the United Nations ... [to] accede to the Convention upon approval by the Meeting of the Parties'. Article 25.3 has been added to the UNECE Water Convention by means of an Amendment in 2004 (see UNECE, Amendment to Articles 25 and 26 of the Convention (UN Doc. ECE/MP.WAT/14, 12 January 2004), which has entered into force on 6 February 2013. See also S. McCaffrey, this issue; and A. Rieu-Clarke and R. Kinna, this issue.
} 
relationship between the Draft Articles and the Model Provisions implies that, were the latter to be followed by more countries, the Draft Articles themselves could be deemed to have a broader impact. However, the real point is once again whether the current (and any future) form of the Draft Articles requires such sophisticated linkages to enhance its legal effects.

\section{NORMATIVE PROPOSITIONS, LEGAL EFFECTS, LEGALLY BINDING INSTRUMENTS AND CUSTOMARY INTERNATIONAL LAW}

As noted above, the Draft Articles in their current form have already had some influence on the development of a number of international instruments. In addition, they have also been referred to by a number of national courts, including the Supreme Court of Justice in Costa Rica. ${ }^{70}$ As such, the Draft Articles already have had some impact on State practice. Uruguay, speaking at the $2013 \mathrm{UN}$ deliberations on behalf of the signatories to the Guarani Aquifer Agreement, made a compelling point that the Draft Articles in their current form constitute 'normative propositions'. ${ }^{71}$ This contention would not contradict the position of those countries that, quite rightly, assert that in their current form, the Draft Articles are not legally binding. ${ }^{72}$ Regardless, given how international law can emerge and evolve, it is reasonable to ask whether a non-legally binding international instrument can, nonetheless, have legal effects. Practice in the field of international environmental law, especially in decisions taken by conferences of the parties (COPs) to multilateral environmental agreements, suggests that this question can be answered in the affirmative. ${ }^{73}$

The logical questions resulting from this assessment would then be: what is meant by legal effects, and what does Uruguay mean when it refers to the Draft Articles as being normative propositions? It can be argued that the Draft Articles provide a platform of substantive and procedural rules that States can use as guidance when negotiating an agreement to manage their transboundary aquifers. The effects are legal insofar as what is suggested in the Draft Articles, as well as in the Model Provisions, constitutes a normative framework. The legal effects are not legally binding because they are not enforceable before any court. If a country does not use the Draft Articles as guidance or does not take them into account when negotiating a transboundary aquifer agreement, it would not be acting contrary to international law. Moreover, its actions would not trigger or impose any State responsibility or liability upon itself. In other words, legal effects can arise from a UN General Assembly Resolution that provides for a declaration of principles, in a way similar to COP decisions.

Considering the above, it is appropriate to question whether the relevance and legal impact of the Draft Articles would be any different if they were translated into a fully-fledged treaty. On the one hand, according to the principle of pacta sunt servanda, the answer would be affirmative where a convention is in force and imposes obligations upon ratifying States. ${ }^{74}$ It is clear that substantive and procedural obligations present in a treaty are binding upon the States party to that treaty and that breaching them would constitute a violation of

\footnotetext{
${ }^{70}$ Decision of the Supreme Court of Justice of Costa Rica, Constitutional Chamber, Voto N. 10-006922 (16 April 2010), at paragraph XIII; as discussed by N. Boeglin, 'Acuíferos Transfronterizos: Respuestas Desde el Derecho Internacional y Vacíos en Centroamérica’, 123:3 Boletín Geológico y Minero (2012), 240.

${ }^{71}$ See Statement by Uruguay, n. $\underline{35} 36$ above, at 3 .

72 See Statement by Japan, n. 4546 above, at 3; Statement by India, n. 5153 above, at 3.

${ }^{73}$ See J. Brunnée, 'COPing with Consent: Law-Making Under Multilateral Environmental Agreements', 15:1 Leiden Journal of International Law (2002), 1; F. Romanin Jacur, 'Les Conférences des Parties des Conventions Internationales de Protection de l'Environnement en Droit International Général' in: L. Rajamani and S. Maljean Dubois (eds.), Implementation of International Environmental Law (Nijhoff, 2011), 251.

${ }^{74}$ Vienna Convention on the Law of Treaties (Vienna, 22 May 1969, in force 27 January 1980), Article 26.
} 
international law. On the other hand, the legal nature of an obligation under international law depends also on two other considerations.

First, the wording of that obligation can determine whether it is legally binding only in principle, or also in practice. If a treaty obligation is drafted in very general or ambiguous terms, it may make a breach very difficult to prove and State responsibility almost impossible to establish before a court. Second, and more relevant to the management of transboundary aquifers, obligations are legally binding where they reflect customary international law. ${ }^{75}$ Where an obligation reflects customary international law, it does not matter whether the provision embodying the obligation is found in a legally binding instrument, a non-binding UNGA Resolution, or a non-binding COP Decision. That obligation will have legally significant consequences.

Accordingly, the question is whether the norms contained in the Draft Articles reflect customary international law in the field of transboundary aquifer management. This is where the debate is probably most heated and evident, for example, in the diverging opinions of Portugal and the US discussed above.

The Draft Articles, however, contain at least one key obligation that is widely acknowledged as a customary norm of international law: the obligation not to cause significant harm to neighbouring countries. ${ }^{76}$ While it has never been specifically applied in the context of a transboundary aquifer dispute, the principle is widely accepted as part of international water law and appears in some form in every transboundary aquifer agreement to date. ${ }^{77}$

In addition, the Draft Articles contain a number of principles that appear to be emerging customary international legal norms applicable to the management of transboundary aquifers. In particular, the obligation to regularly exchange data and information, ${ }^{78}$ and the corollary duty to monitor and, where possible, generate additional data, ${ }^{79}$ are found in a number of contemporary transboundary aquifer arrangements. ${ }^{80}$ Similarly, the obligation of prior notification of planned activities ${ }^{81}$ is also found in various relevant agreements. ${ }^{82}$

Another procedural obligation that seems to have acquired customary international law status in the context of minimizing significant transboundary harm is the obligation to undertake an environmental impact assessment. It is unclear, however, the extent to which this customary norm is obligatory in the context of transboundary aquifers. Recent case law by the International Court of Justice can be interpreted as raising the legal bar of such obligation to

\footnotetext{
${ }^{75}$ Customary international law refers to international law that is grounded in States' conduct rather than codified rules. It emerges from the practice of States that is both broad and consistent, and justified by a sense that such conduct is legally appropriate and mandated, rather than simply morally proper or imposed under threat of reprisal. See M. Shaw, International Law, $6^{\text {th }}$ edn (Cambridge University Press, 2008), at 72 and I. Brownlie, Principles of Public International Law, $7^{\text {th }}$ edn (Oxford University Press, 2008), at 6.

${ }^{76}$ See UNGA Resolution A/RES/63/124, n. 2 above, Article 6. See also Trail Smelter (United States v. Canada) Arbitration, [1938/1941] 13 RIAA 1905; ICJ 8 July 1996, Legality of the Use by a State of Nuclear Weapons in Armed Conflict, Advisory Opinion, [1996] ICJ Rep. 226, paragraph 29; ICJ 9 April 1949, The Corfu Channel Case (United Kingdom v. Albania), [1949] ICJ Rep. 4, at 22.

77 G. Eckstein, 'Managing Buried Treasure Across Frontiers: The International Law of Transboundary Aquifers', 36:5 Water International (2011), 579.

${ }^{78}$ See UNGA Resolution A/RES/63/124, n. 2 above, Article 8.

${ }^{79}$ Ibid., Article 13.

${ }^{80}$ See G. Eckstein, n. 7780 above, at 578.

${ }^{81}$ UNGA Resolution A/RES/63/124, n. 2 above, Article 15.

${ }^{82}$ See G. Eckstein, n. 7780 above, at 578-579.
} 
the level of customary international law, but only in the context of proposed industrial activities. ${ }^{83}$ Furthermore, the fact that the Draft Articles reference environmental impact assessment in Articles 15 and $18,{ }^{84}$ but without a clear-cut requirement to undertake such an activity, raises doubts as to the customary nature of this obligation in the context of transboundary aquifer management. The same can be argued when analyzing the provisions of the Guarani Aquifer Agreement, where the possibility of an environmental impact assessment is mentioned without any binding requirements. ${ }^{85}$ Despite the difficulties in determining when an obligation acquires customary international law status, the form of the legal instrument in which they are found does not necessarily impact their applicability, or even enforceability.

\section{CONCLUSION}

The progression of legal development is a dynamic process that often requires years to evolve. Hence, the impact and effectiveness of the Draft Articles may not necessarily be dependent on their codification and implementation as a binding legal instrument, or even on agreement as non-binding guidelines. Rather their true impact will be measured in relation to the degree to which States embrace the various principles and norms contained in the articles as their practice. In addition, it will depend on the ability and desire of States to accept and employ those articles as a framework for more detailed bilateral and regional aquifer agreements. In the words of Franklin D. Roosevelt, 'There are many ways of going forward, but only one way of standing still.'

Gabriel Eckstein is Professor in Law at Texas A\&M University School of Law in Fort Worth, Texas, USA. Professor Eckstein also is Director of the International Water Law Project, and serves on the executive boards of the International Water Resources Association and the International Association for Water Law.

Francesco Sindico is Reader in International Environmental Law at the Law School of the University of Strathclyde, Glasgow, UK, Director of the Strathclyde Centre for Environmental Law and Governance and Programme Leader of the Strathclyde LLM in Climate Change Law and Policy. In his work on transboundary aquifer management Francesco has been collaborating closely with UNESCO-International Hydrological Programme ISARM (International Shared Aquifers Resources Management).

\footnotetext{
${ }^{83}$ ICJ 20 April 2010, Pulp Mills on the River Uruguay (Argentina v. Uruguay), [2010] ICJ Rep. 14, at paragraph 204. For a different opinion, arguing that the obligation to undertake an environmental impact assessment is now part of general international environmental law, see O. McIntyre, 'The Proceduralization and Growing Maturity of International Water Law: Case Concerning Pulp Mills on the River Uruguay (Argentina v. Uruguay)', 22:3 Journal of Environmental Law (2010), 475.

${ }^{84}$ UNGA Resolution A/RES/63/124, n. 2 above, Articles 15 and 18.

${ }^{85}$ Guarani Aquifer Agreement, n. 6 above, Articles 9 and 10.
} 